\title{
Thymic Hyperplasia in Patients with Graves' Disease Identification of Thyrotropin Receptors in Human Thymus
}

\author{
Masami Murakami, ${ }^{*}$ Yasuhiro Hosoi, ${ }^{*}$ Tetsuo Negishi, ${ }^{\star}$ Yuji Kamiya, ${ }^{*}$ Kazuya Miyashita, ${ }^{*}$ Masanobu Yamada, \\ Tokuji Iriuchijima, ${ }^{*}$ Hideaki Yokoo, ${ }^{\ddagger}$ Ichiro Yoshida, ${ }^{\S}$ Yoshito Tsushima,,${ }^{\|}$and Masatomo Mori ${ }^{\star}$ \\ ${ }^{*}$ First Department of Internal Medicine, ${ }^{\ddagger}$ Department of Pathology, and ${ }^{\S}$ Second Department of Surgery, Gunma University School of \\ Medicine, Maebashi 371, Japan; and ${ }^{\|}$Department of Radiology, National Defense Medical College, Tokorozawa 359, Japan
}

\begin{abstract}
Thymic size and density were studied in 23 untreated patients with Graves' disease and 38 control subjects using computed tomography. Both thymic size and density were higher in untreated patients with Graves' disease than in control subjects in the age-matched group. After treatment with antithyroid drugs, both thymic size and density were significantly reduced, with a concomitant decrease in thyrotropin receptor antibodies. PCR of human thymic cDNA using primers for human thyrotropin receptor amplified a fragment in a size expected for the receptor, and its nucleotide sequence was identical to human thyrotropin receptor cDNA in the thyroid. Northern blot analysis of human thymic $\operatorname{poly}(\mathrm{A})^{+}$RNA demonstrated the presence of the full length form of thyrotropin receptor mRNA. Western blot analysis of human thymic membrane using anti-thyrotropin receptor peptide antibodies demonstrated a band of $\sim 100 \mathrm{kD}$ that was also observed in the thyroid membrane. Immunohistochemistry of thymic tissue using mouse antihuman thyrotropin receptor monoclonal antibodies demonstrated the immunostaining of epithelial cells. These results indicate that thymic hyperplasia is apparently associated with Graves' disease and suggest that thymic thyrotropin receptor may act as an autoantigen that may be involved in the pathophysiology of development of Graves' disease. $(J$. Clin. Invest. 1996. 98:2228-2234.) Key words: computed tomography $\bullet$ polymerase chain reaction - Northern blot analysis $\bullet$ Western blot analysis $\bullet$ immunohistochemistry
\end{abstract}

\section{Introduction}

Graves' disease results from the development of antibodies for the thyrotropin $(\mathrm{TSH})^{1}$ receptor that stimulate thyroid functions and cause thyroid enlargement $(1,2)$. By analogy with antireceptor antibodies in Graves' disease, antibodies for the nicotinic acetylcholine receptor exist in patients with myasthe-

Address correspondence to Masami Murakami, First Department of Internal Medicine, Gunma University School of Medicine, Maebashi 371, Japan. Phone: 272-20-8126; FAX: 272-20-8136; E-mail: mmu rakam@sb.gunma-u.ac.jp

Received for publication 1 April 1996 and accepted in revised form 10 September 1996.

1. Abbreviations used in this paper: CT, computed tomography; HU, Hounsfield unit; TRAb, TSH receptor antibody; TSH, thyrotropin.

J. Clin. Invest.

(c) The American Society for Clinical Investigation, Inc. 0021-9738/96/11/2228/07 \$2.00

Volume 98, Number 10, November 1996, 2228-2234 nia gravis, in which the thymus plays a pivotal role in the pathogenesis, and thymectomy is frequently found to improve clinical manifestations (3). It is noteworthy that the acetylcholine receptor is present not only at the neuromuscular junction, but in the thymus (4-10). The thymic acetylcholine receptor has been suggested to be involved in initiating or perpetuating the autoimmune response (3) and in developing thymic hyperplasia or thymoma in myasthenia gravis (4). However, limited information has been available concerning the pathophysiological roles of the thymus in Graves' disease.

In old literature, a hyperplastic thymus was suggested to play an etiological role in Graves' disease (11), and thymic enlargement was reported in patients with Graves' disease (12). Thymic enlargement has also been demonstrated as a mediastinal tumor in some cases with Graves' disease (13-15). Histological examination of the thymus of patients with Graves' disease shows a thymic medullary lymphoid follicle formation with active germinal centers (16), which has been described in only two other clinical settings, myasthenia gravis and systemic lupus erythematosus (3).

Since computed tomography (CT) has reportedly been useful in evaluating the thymus (17), we employed CT scan in the present study to determine the size and density of the thymus in Graves' patients before and after treatment with antithyroid drugs. In addition, an attempt was made to identify TSH receptors in human thymus. The results described here show the significant hyperplasia of the thymus in Graves' patients and demonstrate the possible existence of TSH receptors in human thymus.

\section{Methods}

Measurement of thymic size and CT attenuation values. Because it has been reported that the size and density of the normal thymus decrease with increasing age (17), the ages of patients with Graves' disease and normal control subjects were classified into four groups (20-29, 3039, 40-49, and 50-59). Patients with Graves' disease were diagnosed based on clinical hyperthyroidism showing increased thyroid hormone levels, suppressed TSH levels, positive TSH-receptor antibodies (TRAb), and increased ${ }^{123}$ I thyroidal uptake. CT scans were performed on 23 untreated patients with Graves' disease and 38 normal control subjects, using rotate-rotate system CT (SCT-5000T; Shimazu Corp., Kyoto, Japan). None of the control subjects had a history of thyroid disease. All scans were obtained in inspiration at 0.5 or 1-cm intervals. Thymic size and density were measured at the level where the thymus appears most prominently, usually at the level of the bifurcation of the trachea. The thymus was shown at a setting of level 30 and width 750, and the border of the thymus was traced by the cursor. Thymic size was then measured as an area $\left(\mathrm{mm}^{2}\right)$, and thymic density was measured as averaged CT attenuation value (Hounsfield Unit, HU) using SCT-5000T. A CT scan of the thymus was performed in 13 patients whose values could be monitored before and after treatment with methimazole or propylthiouracil for 5 to 24 mo. 
Thymic size and CT attenuation values were compared at the same level in those patients before and after treatment.

Measurement of free T4, free T3, TSH, and TRAb. Serum free T4, free T3, and TSH were measured by EIA kit (DAINABOT, Tokyo, Japan). TRAb was measured by a radioreceptor assay kit (Cosmic Corp., Tokyo, Japan).

Preparation of RNA. Thyroid tissue was obtained at the time of thyroidectomy from a patient with Graves' disease. Histologically examined nonneoplastic thymic tissues were obtained at the time of surgery from three patients with thymoma and a patient with lung carcinoma. Total RNA was isolated from thyroid and thymic tissues by the modified acid guanidinium thiocyanate-phenol-chloroform method according to Chomczynski and Sacchi (18). Normal human thymus total RNA was also obtained from Clontech (Palo Alto, CA).

PCR amplification of the TSH receptor and sequence analysis. Single strand cDNA synthesis was performed on $1 \mu \mathrm{g}$ of total RNA using a First-Strand cDNA Synthesis kit (Pharmacia LKB Biotechnology, Tokyo, Japan). For PCR, the synthesized sense and antisense primers for human TSH receptor were AGAAATAGCCCCGAGTCCCGTGGA (nucleotides -26--3) and GGTTTCATTGCATAGTCCCT $(518-537)(19,20)$. One tenth of the reverse transcription reaction or $1 \mathrm{ng}$ of normal human thymus cDNA (Clontech) was amplified in $100 \mu \mathrm{l}$ of PCR buffer (TAKARA SHUZO, Otsu, Japan) containing 50 pmol of each oligonucleotide primer. $1 \mathrm{U}$ Taq DNA polymerase (TAKARA SHUZO) was added after the first denaturation $\left(5 \mathrm{~min}\right.$ at $\left.95^{\circ} \mathrm{C}\right)$. Samples were then subjected to 40 cycles consisting of $2 \mathrm{~min}$ at $94^{\circ} \mathrm{C}, 2 \mathrm{~min}$ at $55^{\circ} \mathrm{C}$, and $3 \mathrm{~min}$ at $72^{\circ} \mathrm{C}$. The last extension was carried out for $15 \mathrm{~min}$. The reaction products were analyzed by $1 \%$ agarose gel electrophoresis, and the resulting bands were visualized by ethidium bromide staining. In some experiments, the electrophoretically separated PCR products were denatured in denaturing solution $(1.5 \mathrm{M} \mathrm{NaOH}, 0.5 \mathrm{M} \mathrm{NaCl})$ for $15 \mathrm{~min}$, and transferred onto a nylon membrane (Hybond $\mathrm{N}^{+}$; Amersham Life Science, Tokyo, Japan) overnight in $0.4 \mathrm{M} \mathrm{NaOH}$. The filter was prehybridized with a hybridization buffer $(50 \%$ formamide, $5 \%$ dextran sulfate, $50 \mathrm{mM}$ Hepes, $5 \times$ SSC: $150 \mathrm{mM}$ sodium chloride and $15 \mathrm{mM}$ trisodium citrate, $2 \times$ Denharts' solution and $20 \mu \mathrm{g} / \mathrm{ml}$ denatured salmon sperm DNA) at $42^{\circ} \mathrm{C}$ for $2 \mathrm{~h}$. Subsequently, the filter was hybridized overnight at $42^{\circ} \mathrm{C}$ with a human TSH-receptor cDNA probe (kindly provided by Dr. Gilbert Vassart, reference 19) labeled with $\left[\alpha{ }^{32} \mathrm{P}\right] \mathrm{dCTP}$ by random priming method (Pharmacia LKB Biotechnology). The filter was washed twice in $2 \times \mathrm{SSC}, 0.1 \%$ SDS at $25^{\circ} \mathrm{C}$ for $10 \mathrm{~min}$, and twice in $0.1 \times \mathrm{SSC}, 0.1 \% \mathrm{SDS}$ at $55^{\circ} \mathrm{C}$ for $1 \mathrm{~h}$. Autoradiography was attained by exposing the filter for $6 \mathrm{~h}$ to $\mathrm{x}$-ray film (Kodak XAR-2; Eastman Kodak Co., Rochester, NY) at $-70^{\circ} \mathrm{C}$ with an intensifying screen.

The cDNA fragment of the TSH receptor amplified by PCR was cloned into pCR ${ }^{\mathrm{TM}} \mathrm{II}$ (Invitrogen Corp., San Diego, CA) and a clone possessing the insert was sequenced using the Sequenase 2.0 kit (United States Biochemical, Cleveland, $\mathrm{OH}$ )

Table I. Comparison of Thymic Size $\left(\mathrm{mm}^{2}\right)$ between Untreated Patients with Graves' Disease and Control Subjects in Four Age Groups

\begin{tabular}{llllllllll}
\hline & \multicolumn{2}{l}{ Patients with Graves' disease } & & \multicolumn{3}{c}{ Control subjects } & \\
\cline { 2 - 3 } \cline { 6 - 7 } Age group & $n$ & Mean & SD & & $n$ & Mean & SD & \\
\hline $20-29$ & 7 & 977.9 & 276.2 & 7 & 219.9 & 181.3 & $P<0.01$ \\
$30-39$ & 6 & 981.8 & 352.7 & 10 & 183.3 & 90.6 & $P<0.01$ \\
$40-49$ & 5 & 751.0 & 293.0 & & 13 & 176.0 & 95.2 & $P<0.05$ \\
$50-59$ & 5 & 630.4 & 428.0 & 8 & 142.8 & 57.8 & $P<0.01$
\end{tabular}

Thymic size was measured by means of computed tomography as described in Methods.
Northern blot analysis of TSH-receptor $m R N A$. Poly(A) ${ }^{+}$RNA was isolated using oligo-dT Dynabeads (Dynal, Tokyo, Japan) according to the manufacturer's instructions. $1 \mu \mathrm{g}$ of poly $(\mathrm{A})^{+}$RNA was electrophoresed on a $1.2 \%$ agarose gel containing $2 \mathrm{M}$ formaldehyde and transferred overnight in 20× SSC to a nylon membrane (Biodyne; Pall BioSupport Corp., East Hills, NY). Poly(A) ${ }^{+}$RNA was cross-linked to the nylon with an ultraviolet Stratalinker. The filter was prehybridized with a hybridization buffer $(50 \%$ formamide, $0.2 \%$ SDS, $5 \%$ dextran sulfate, $50 \mathrm{mM}$ Hepes, $5 \times$ SSC, $5 \times$ Denharts' solution, and $250 \mu \mathrm{g} / \mathrm{ml}$ denatured salmon sperm DNA) at $65^{\circ} \mathrm{C}$ for $2 \mathrm{~h}$. Subsequently, the filter was hybridized overnight at $65^{\circ} \mathrm{C}$ with a labeled human TSH-receptor cRNA probe that was synthesized by in vitro transcription of Xba I linearized pGEM 11zf/human TSH receptor using T7 polymerase and $\left[\gamma^{-}{ }^{32} \mathrm{P}\right] \mathrm{UTP}$. The filter was washed twice in $2 \times \mathrm{SSC}, 0.1 \% \mathrm{SDS}$ at $25^{\circ} \mathrm{C}$ for $10 \mathrm{~min}$, and twice in $0.1 \times \mathrm{SSC}$, $0.1 \%$ SDS at $65^{\circ} \mathrm{C}$ for $1 \mathrm{~h}$. Autoradiography was attained by exposing the filter for $24 \mathrm{~h}$ to $\mathrm{x}$-ray film (Kodak XAR-2) at $-70^{\circ} \mathrm{C}$ with an intensifying screen.

Western blot analysis of TSH receptors. Western blot analysis of TSH receptors was performed as previously described (21), with minor modifications. Rabbit polyclonal antibodies against human thyrotropin receptor peptide (amino acid 32-56) $(21,22)$ were purified by affinity column chromatography using TSH-receptor peptide (amino acid 32-56) coupled with 2-fluoro-1-methylpyridinium toluene-4-sulfonate activated cellulofine (SEIKAKAGU Corp., Tokyo, Japan). Thyroid tissue from a patient with Graves' disease and nonneoplastic thymic tissue from a patient with thymoma were homogenized using Polytron ${ }^{\mathrm{TM}}$ in 5 vol of homogenizing buffer (10 mM Tris$\mathrm{HCl}, 5 \mathrm{mM} \mathrm{NaCl}, 1 \mathrm{mM}$ EDTA, $1 \mathrm{mM}$ PMSF, 20\% glycerol, $\mathrm{pH}$ 7.4). After centrifugation at $500 \mathrm{~g}$ at $4^{\circ} \mathrm{C}$ for $10 \mathrm{~min}$, resultant supernatant was centrifuged at $100,000 \mathrm{~g}$ at $4^{\circ} \mathrm{C}$ for $1 \mathrm{~h}$. Precipitated membrane fraction was resuspended in homogenizing buffer. $100 \mu \mathrm{g}$ of the membrane fraction in $10 \mu \mathrm{l}$ was mixed with an equal volume of sample buffer $(62.5 \mathrm{mM}$ Tris- $\mathrm{HCl}, 10 \%$ glycerol, 2\% SDS, 5\% 2-mercaptoethanol), boiled at $93^{\circ} \mathrm{C}$ for $5 \mathrm{~min}$, and electrophoresed using a $7.5 \%$ running gel for $1 \mathrm{~h}$ at constant $35 \mathrm{~mA}$. The separated proteins were transferred onto a polyvinylidene difluoride membrane (Biodyne) for $3 \mathrm{~h}$ at $80 \mathrm{~V}$ on ice. The filter was washed with TBS buffer $(50 \mathrm{mM}$ Tris- $\mathrm{HCl}, 0.2 \mathrm{M} \mathrm{NaCl}, \mathrm{pH} 7.5$ ) and incubated in TBS buffer containing $5 \%$ skim milk at $4^{\circ} \mathrm{C}$ overnight. The filter was washed with TBS buffer and incubated with $0.01 \mathrm{mg} / \mathrm{ml}$ purified TSH-receptor peptide (amino acid 32-56) antibodies in TBS buffer containing $1 \%$ skim milk at $25^{\circ} \mathrm{C}$ for $2 \mathrm{~h}$. After washing with TBS buffer containing $0.05 \%$ Tween 20 for $20 \mathrm{~min}$ three times, the filter was incubated with goat anti-rabbit IgG horseradish peroxidase conjugate (Amersham Life Science) in $1 \%$ skim milk in TBS buffer at $25^{\circ} \mathrm{C}$ for $1 \mathrm{~h}$. The filter was washed with TBS buffer containing $0.05 \%$ Tween 20 for $20 \mathrm{~min}$ three times, the proteins were detected using an ECL kit (Amersham Life Science). Autoradiography was attained by exposing the filter for $1 \mathrm{~min}$ to Hyperfilm ECL (Amersham Life Science).

Table II. Comparison of Mean Thymic CT Attenuation Values (HU) between Untreated Patients with Graves' Disease and Control Subjects in Four Age Groups

\begin{tabular}{ccccccccc}
\hline & \multicolumn{3}{c}{$\begin{array}{c}\text { Patients with Graves' } \\
\text { disease }\end{array}$} & & \multicolumn{3}{c}{ Control subjects } & \\
\cline { 2 - 3 } \cline { 6 - 7 } Age group & $n$ & Mean & SD & & & Mean & SD & \\
\hline $20-29$ & 7 & 24.0 & 41.7 & 7 & -24.0 & 39.0 & $P<0.05$ \\
$30-39$ & 6 & 34.5 & 16.6 & 10 & -38.6 & 26.6 & $P<0.001$ \\
$40-49$ & 5 & -31.1 & 51.9 & 13 & -69.1 & 17.1 & $P<0.05$ \\
$50-59$ & 5 & -31.3 & 12.0 & 8 & -83.8 & 29.9 & $P<0.01$
\end{tabular}

Mean thymic CT attenuation value was measured as described in Methods. 
Immunohistochemistry of TSH receptors. Immunohistochemical studies using mouse $\mathrm{mAb}$ were performed as previously described (23), with minor modifications. Briefly, the frozen sections of surgically resected thyroid and nonneoplastic thymic tissues were fixed in cold acetone for $10 \mathrm{~min}$. After incubation with $0.3 \% \mathrm{H}_{2} \mathrm{O}_{2}$-methanol solution and $10 \%$ normal goat serum for 30 min each to block nonspecific staining, they were reacted with mouse anti-human TSHreceptor $\mathrm{mAb}$ (1:250; TRANSBIO, Boulogne, France), which recognize amino acids 604-764 of human TSH receptor (24), overnight at $4^{\circ} \mathrm{C}$, and visualized by a biotin-streptavidin-amplified immunoperoxidase kit (Histofine; Nichirei, Tokyo, Japan). 3,3'-Diaminobenzidine was used as a chromogen. Subsequently, the sections were lightly counterstained by hematoxylin. For thymic tissue, the adjacent sections were immunostained by antibodies against cytokeratin AE1/ AE3 (Boehringer Mannheim, Mannheim, Germany). The negative control sections were covered with normal goat serum (diluent of the primary antibody) instead of the primary antibody.

Statistics. Results are expressed as mean \pm SD. Statistical differences were calculated by Student's $t$ test or paired $t$ test.

\section{Results}

Thymic size and CT attenuation values in untreated patients with Graves' disease and control subjects. Table I summarizes the comparison of thymic size in untreated patients with Graves' disease and control subjects who were divided into four age-matched groups. In both Graves' patients and control subjects, thymic size decreased with increasing age. Thymic size was greater in untreated patients with Graves' disease than in control subjects in all age groups. Table II summarizes

A

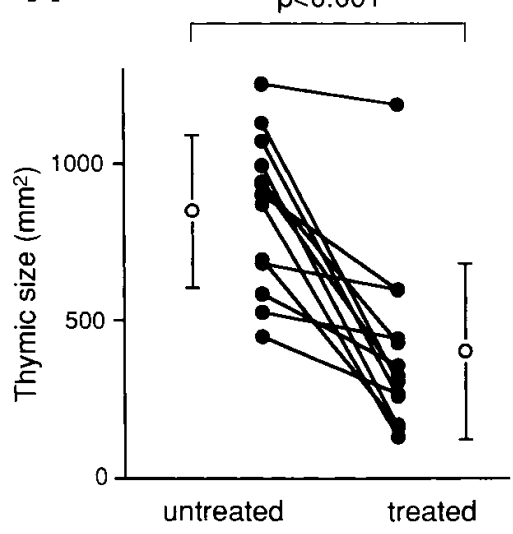

B

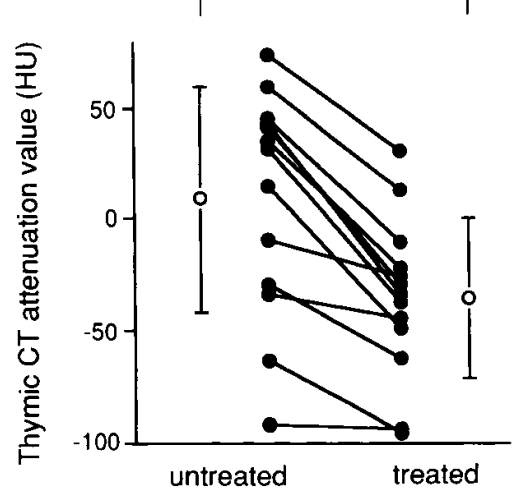

Figure 1. Changes in the size $(A)$ and mean $\mathrm{CT}$ attenuation value $(B)$ of the thymus in patients with Graves' disease during treatment with antithyroid drugs. All the treated patients exhibited euthyroid state, and decreased TRAb $(38.1 \pm 17.5 \%$ before and $5.2 \pm 5.8 \%$ after treatment, $P<$ 0.001). Thymic size and mean CT attenuation values were measured as described in Methods. Closed circles represent individual cases and open circles represent mean values before and after treatment. Error bars indicate SD.
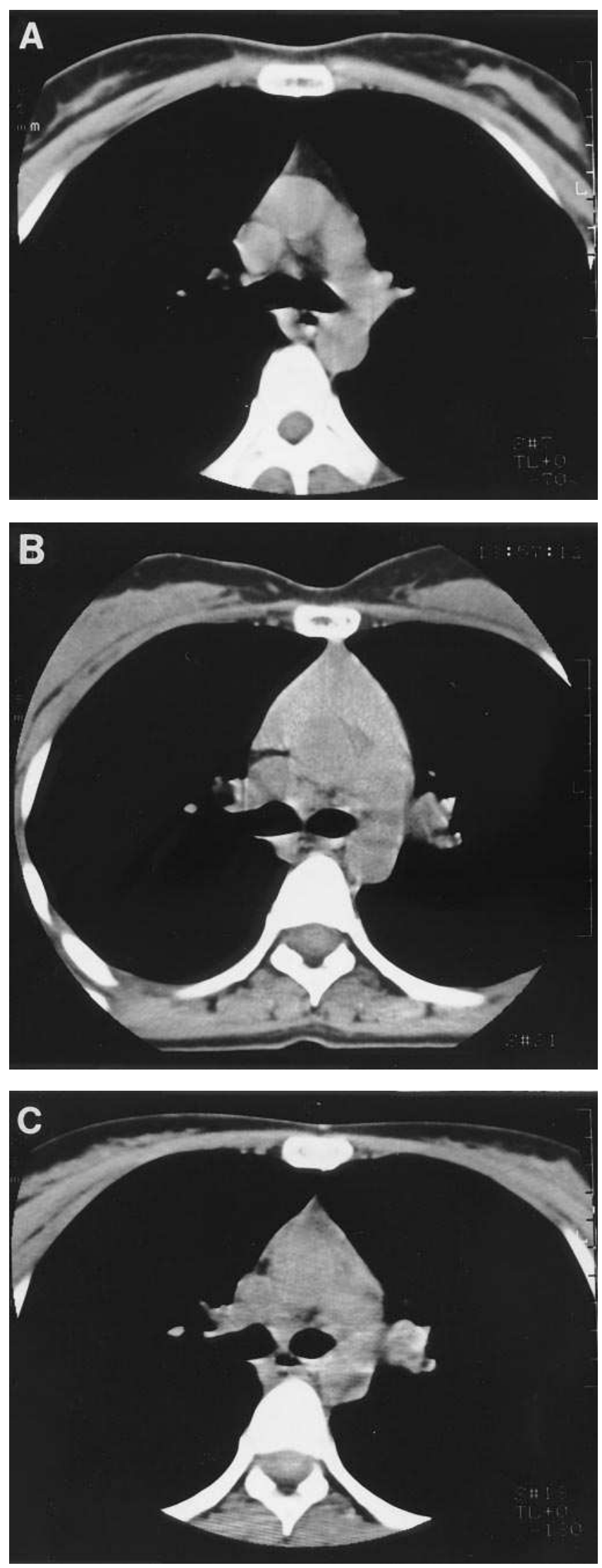

Figure 2. Representative CT scans of the thymus of a control subject $(A)$, and untreated $(B)$ and treated $(C)$ state of a patient with Graves' disease. The control subject was a 30-yr-old female, and the patient with Graves' disease was a 30-yr-old female treated with methimazole for $1 \mathrm{yr}$. 
A

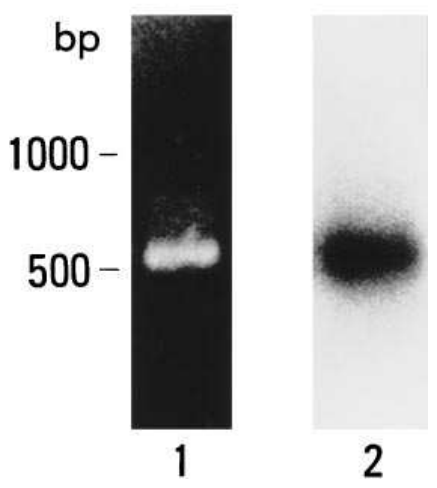

B

C

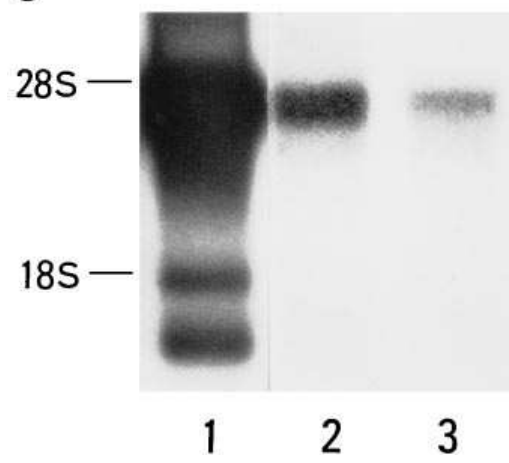

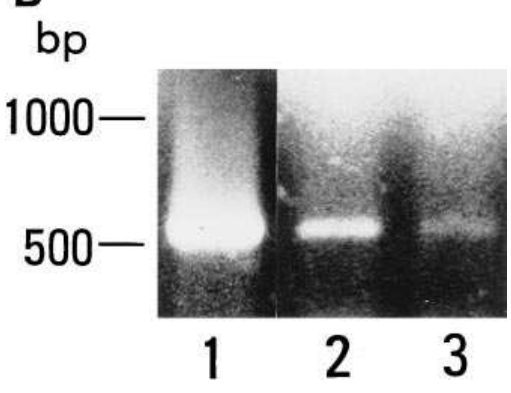

Figure 3. (A) PCR amplification of human thymus cDNA using oligonucleotide primers specific for human TSH receptor. Ethidium bromide staining (lane 1) and Southern blot analysis using cDNA probe for human TSH receptor (lane 2) are shown. Normal human thymus cDNA was obtained from Clontech Laboratories, and $1 \mathrm{ng}$ of cDNA was used for PCR. (B) Reverse transcription PCR of thyroid (lane 1) and thymus (lanes 2 and 3 ) RNA using oligonucleotide primers specific for human TSH receptor. Thyroid tissue was obtained from a patient with Graves' disease, and nonneoplastic thymic tissues were obtained from patients with thymoma. $1 \mu \mathrm{g}$ of total RNA was used for reverse transcription, and one tenth of the reverse transcription reaction was used for PCR. (C) Northern blot analysis of thyroid (lane 1) and thymus (lanes 2 and 3) poly(A) ${ }^{+}$RNA using cRNA probe for human TSH receptor. Thyroid RNA was ob-

tained from a patient with Graves' disease, and thymus RNA was obtained from Clontech Laboratories (lane 2) and a patient with lung carcinoma (lane 3). $1 \mu \mathrm{g}$ of poly(A) ${ }^{+}$RNA was used for Northern blot analysis. Analyses were performed as described in Methods.

the comparison of thymic CT attenuation values in untreated patients with Graves' disease and control subjects. Thymic CT attenuation values also decreased with increasing age, and thymic CT attenuation values were greater in Graves' patients than in control subjects in all age groups.

Changes in thymic size and density during antithyroid drug therapy. The changes in thymic size and CT attenuation values were studied in 13 patients with Graves' disease before and after treatment with antithyroid drugs for 5 to 24 mo. After treatment, all patients exhibited euthyroid state, and TRAb significantly decreased $(38.1 \pm 17.5 \%$ before and $5.2 \pm 5.8 \%$ after treatment, $P<0.001$, by paired $t$ test). As shown in Fig. 1 $A$, thymic size significantly decreased after treatment $(852 \pm$ $245 \mathrm{~mm}^{2}$ before and $402 \pm 280 \mathrm{~mm}^{2}$ after treatment, $P<0.001$, by paired $t$ test). The values of thymic CT attenuation also significantly decreased after treatment $(9.1 \pm 50.7 \mathrm{HU}$ before and

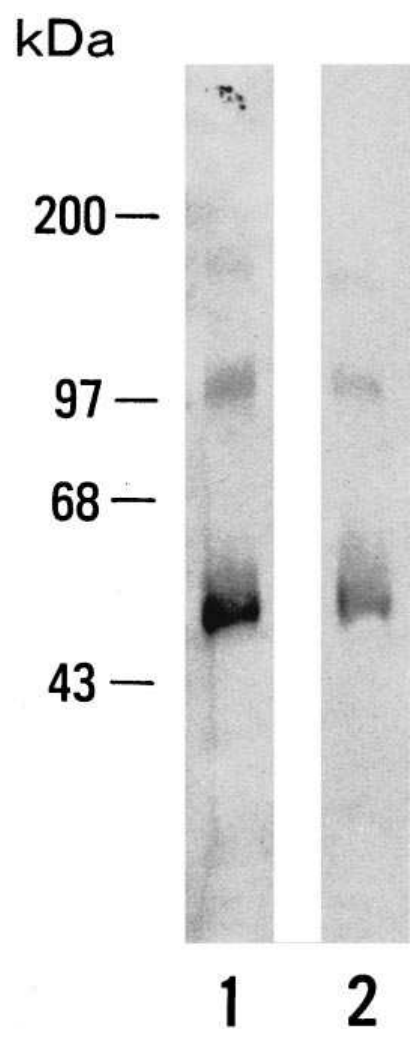

Figure 4. Western blot analysis of TSH receptors in thyroid and thymic tissue. Thyroid tissue was obtained from a patient with Graves' disease and nonneoplastic thymic tissue was obtained from a patient with thymoma. Western blotting using antihuman TSH receptor peptide antibodies demonstrated an apparent band of $\sim 100 \mathrm{kD}$ in both thyroid (lane 1) and thymic (lane 2) tissue. Analyses were performed as described in Methods.

$-35.5 \pm 36.3 \mathrm{HU}$ after treatment, $P<0.01$, by paired $t$ test), as shown in Fig. $1 B$. Fig. $2 A$ shows a representative CT scan of the thymus in a 30 -yr-old female control subject. Fig. $2 B$ shows the thymus in a 30-yr-old woman with untreated Graves' disease, and Fig. $2 C$ shows the thymus in the same patient after $1 \mathrm{yr}$ of treatment with methimazole. The obvious decreases in thymic size and density after treatment were demonstrated.

PCR amplification and Northern and Western blot analyses of TSH receptors in thyroid and thymic tissues. PCR of normal human thymus cDNA demonstrated a single amplified DNA fragment of $563 \mathrm{bp}$, which corresponds to the size expected for the human TSH receptor, as shown in Fig. $3 A$, lane 1 . Southern blot analysis of PCR-amplified product using labeled human TSH receptor cDNA demonstrated a single band of 563 bp, as shown in Fig. $3 A$, lane 2. The nucleotide sequence of the amplified product was identical to the cDNA for the human TSH receptor in the thyroid. Reverse transcription PCR of thyroid RNA demonstrated a single amplified DNA fragment of $563 \mathrm{bp}$, which corresponds to the expected size of the DNA, as shown in Fig. 3 B, lane 1 . The same DNA fragment was amplified in reverse transcription PCR of RNA from nonneoplastic thymic tissues from two patients with thymoma as shown in Fig. 3 B, lanes 2 and 3, although the amount of the amplified product was relatively less than that of the thyroid. As a contamination control, total RNA that was treated in an identical manner except for the substitution of water for reverse transcriptase showed no band (data not shown). The possibility of contamination of genomic DNA could be ruled out in this study because of the presence of five introns between the oligonucleotide primers (25) and because the contamination control showed no amplified product. 

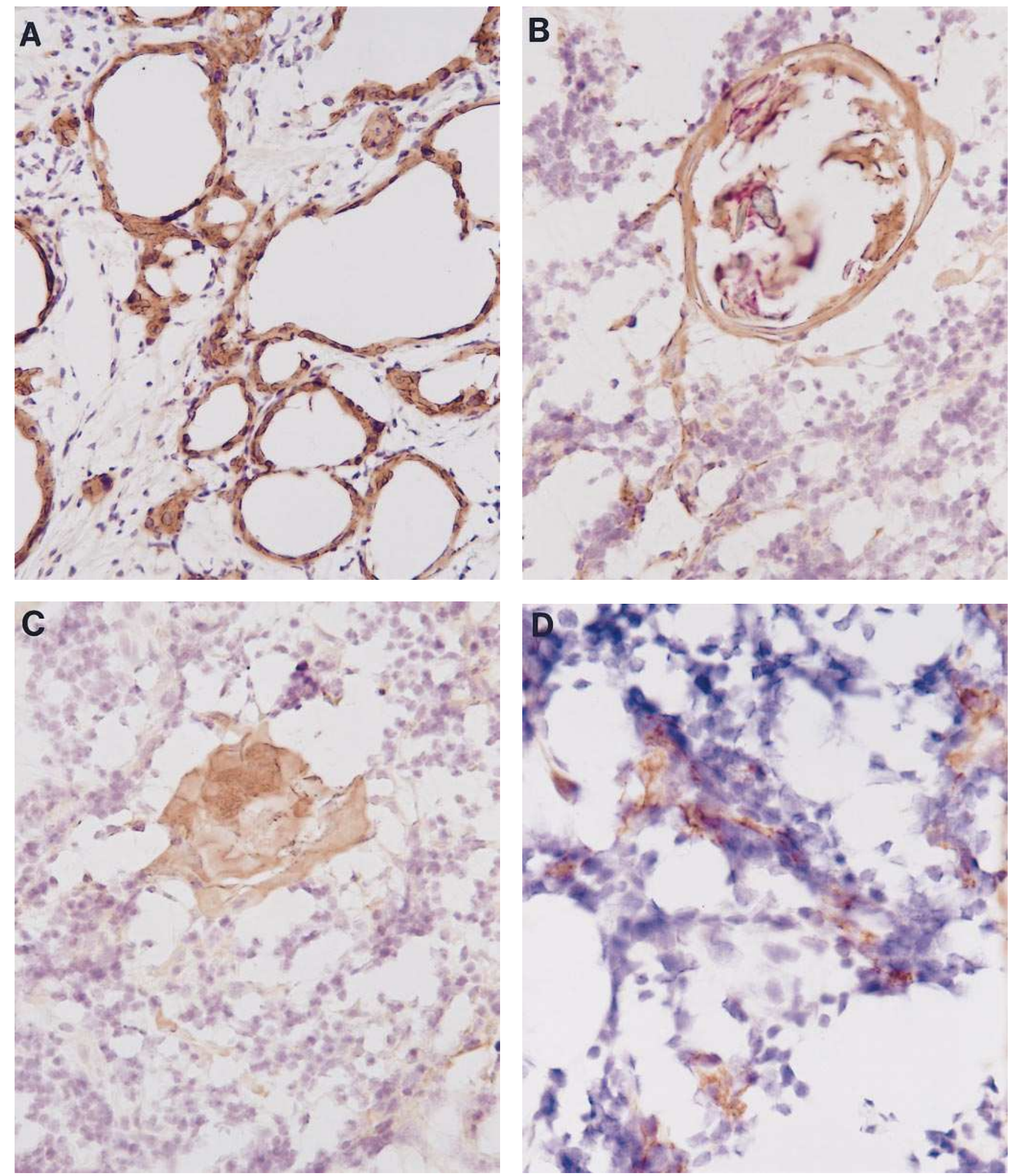

Figure 5. Immunohistochemistry of TSH receptors in thyroid and nonneoplastic thymic tissue using mouse anti-human TSH-receptor mAb. Thyroid tissue was obtained from a patient with Graves' disease and nonneoplastic thymic tissue was obtained from a patient with thymoma. $(A)$ Immunohistochemistry of the thyroid gland $(200 \times)$. Follicular epithelial cells were stained by mouse anti-human TSH-receptor mAb. $(B$ and $C)$ Immunohistochemistry of the medulla of the thymus $(400 \times)$. The Hassall's corpuscles and their surrounding epithelial cells were immunostained by mouse anti-human TSH receptor mAb. $(D)$ Immunohistochemistry of the cortex of the thymus $(400 \times)$. Cells with ramified processes were immunostained by mouse anti-human TSH-receptor mAb. Immunohistochemistry was performed as described in Methods. 
Northern blot analysis of thyroid poly $(\mathrm{A})^{+}$RNA using the cRNA probe for human TSH receptor revealed three major bands of $\sim 4.3,1.7$, and $1.3 \mathrm{~kb}$, as shown in Fig. $3 C$, lane 1 , as has been reported previously (26). A band of $4.3 \mathrm{~kb}$, corresponding to the full length form of human $\mathrm{TSH}$ receptor mRNA, was detected in thymic poly $(\mathrm{A})^{+}$RNA from Clontech Laboratories and from a patient with lung carcinoma, as shown in Fig. $3 C$, lanes 2 and 3, respectively.

Western blot analysis of thyroid and thymic tissues using purified anti-TSH-receptor peptide (amino acid 32-56) antibodies demonstrated an apparent band of $\sim 100 \mathrm{kD}$ in both tissues (Fig. 4, lanes 1 and 2, respectively). In both tisssues, a band of $50-55 \mathrm{kD}$, presumably degraded forms of the TSH receptor $(27,28)$, was also observed.

Immunohistochemistry of TSH receptors. Immunohistochemistry of thyroid and thymic tissues using mouse anti-human TSH-receptor $\mathrm{mAb}$, which has been verified to be suitable for immunohistochemical study of the TSH receptor (24), is shown in Fig. 5. In thyroid tissue, follicular epithelial cells were immunostained by mouse anti-human TSH receptor $\mathrm{mAb}$ as reported previously (24), as shown in Fig. 5 A. In nonneoplastic thymic tissue, the Hassall's corpuscles and their surrounding epithelial cells were significantly immunostained, as shown in Fig. 5, $B$ and $C$. Process-bearing cells with meshwork arrangement, putative epithelial cells, were also stained as shown in Fig. $5 \mathrm{D}$. The same cells were also immunostained by antibodies against cytokeratin, a marker of epithelial cells, in the adjacent sections (data not shown). In contrast, the thymocytes were not immunostained in these sections. No positive reaction was demonstrated in the negative control sections.

\section{Discussion}

The present study demonstrates that thymic size and CT attenuation values significantly increased in untreated patients with Graves' disease in comparison with control subjects in all age groups examined. Thymic size and CT attenuation values significantly decreased after treatment with antithyroid drugs, with a concomitant decrease in thyrotropin receptor antibodies. The increase in thymic size in untreated patients with Graves' disease is in general agreement with the past observations showing thymic enlargement in patients with Graves' disease by means of pneumomediastinography (12). The precise CT scan results showing the increase in the thymic size and density in untreated patients with Graves' disease suggest that a thymic hyperplasia is highly associated with Graves' disease, presumably reflecting a thymic medullary lymphoid-follicle formation (16). The decrease in thymic size and density by treatment with antithyroid drugs could be produced, at least in part, by an indirect action by lowering circulating thyroid hormone levels, since it has been reported that exogenous thyroid hormone administration to experimental animals resulted in enlargement of both cortical and medullary components of the thymus $(29,30)$, while thyroidectomy induced a reduction of thymic size (31). It has also been suggested that antithyroid drugs not only cause a block of thyroid hormone synthesis, but also have immunosuppressive effects, including lowering TSHreceptor antibody levels (32). Thus, antithyroid drugs might also induce thymic atrophy by mechanisms related to their immunosuppressive effects. These possible mechanisms by which antithyroid drugs decrease the size and density of the thymus remain to be elucidated.
In the present study, TSH receptors were clearly demonstrated in nonneoplastic thymic tissues by PCR amplification, Northern and Western blot analysis, and immunohistochemistry. PCR amplified a TSH receptor fragment, and the nucleotide sequence of its PCR-amplified product was identical to the human TSH receptor existing in the thyroid gland. Northern blot analysis demonstrated thymic mRNA for the TSH receptor in a size identical to the full length form of the receptor. To our knowledge, the present report is the first demonstration by Northern blot analysis of the full length form of TSHreceptor transcripts in human tissues other than the thyroid gland. Smaller bands corresponding to the truncated forms of TSH receptor were not detected in thymic tissue, while they were clearly demonstrated in thyroid tissue. Since the TSH receptor message level in thymic tissue was less than that of thyroid tissue, the failure of demonstrating smaller bands in thymic tissue may result from the sensitivity of Northern blot analysis in this study. Western blot analysis of thyroid and thymic tissues using anti-human TSH receptor peptide antibodies demonstrated the protein, presumably the TSH receptor, with a molecular weight of $\sim 100 \mathrm{kD}$ in both tissues. Its molecular weight is in general agreement with that of human TSH receptor proteins reported by other investigators $(27,28)$. TSH receptors were demonstrated in follicular epithelial cells in the thyroid by immunohistochemistry using mouse anti-human TSH-receptor mAb, which confirmed the previous observation using the same mAb (24). Immunohistochemistry of thymic tissue using the mouse anti-human TSH-receptor $\mathrm{mAb}$ also demonstrated the presence of immunostained cells in the thymus in the present study. The positive reaction was revealed, at least on a population of the epithelial cells, which was confirmed by immunostaining using antibodies against cytokeratin. These results suggest that TSH receptors are expressed in the epithelial cells of human thymus. The primary antibody used in this study has not been suitable on formalinfixed, paraffin-embedded tissue sections (data not shown), that generally give fine morphology. Our immunohistochemical study was therefore restricted on frozen sections of a surgically resected thyroid and thymic tissue, as reported previously (24). Since detailed analyses could not be performed in this study, the possibility of the presence of TSH receptors in other thymic stromal cells, such as dendritic cells, was not totally excluded. The mouse anti-human TSH-receptor mAb did not stain thymocytes in the present study. However, it has been reported that immunoglobulins of a patient with Graves' disease who had thymus enlargement bound thymocytes and caused thymocyte proliferation (33), which might indicate the presence of TSH receptors in thymocytes. It is therefore possible that the failure to demonstrate the presence of TSH-receptor protein in thymocytes may have resulted from the sensitivity or the characteristics of the antibody used in this study.

The nicotinic acetylcholine receptor has been demonstrated not only at the neuromuscular junctions, but in thymic tissues (4-10). Thymic acetylcholine receptor has been suggested to be involved in developing thymic hyperplasia or thymoma in myasthenia gravis (4). By analogy with thymic acetylcholine receptor, thymic TSH receptor may also be suggested to participate in developing thymic hyperplasia in patients with Graves' disease, as demonstrated in the present study. In addition, thymic acetylcholine receptor has been postulated to be responsible for the initiation or perpetuation of the autoimmune response (3-5), and has been suggested to be involved in 
the aberrant positive selection of the $\mathrm{T}$ cell repertoire that contributes to the development of autoreactive T cells in myasthenia gravis (8). In view of these observations, it is of interest to speculate that TSH receptors in thymic epithelial cells may also be involved in the initiation or perpetuation of the autoimmune response, and in the selection of the $\mathrm{T}$ cell repertoire that may contribute to the development of autoreactive T cells in Graves' disease. To support this hypothesis, it must be elucidated whether TSH receptor-reactive T cells are present in the thymus in patients with Graves' disease in further studies.

The present study opens a novel perspective on investigation of the relationship between thymic hyperplasia and the pathogenesis of Graves' disease.

\section{Acknowledgments}

The authors thank Dr. Gilbert Vassart for kindly providing human TSH-receptor cDNA. The authors also thank Mr. Toshihito Kuwabara for his technical assistance.

This work was supported in part by a grant-in-aid (05670836) to M. Murakami for scientific research from the Ministry of Education, Science and Culture, Japan.

\section{References}

1. Smith, B.R., S.M. McLachlan, and J. Furmaniak. 1988. Autoantibodies to the thyrotropin receptor. Endocr. Rev. 9:106-120.

2. Kohn, L.D., H. Shimura, Y. Shimura, A. Hidaka, C. Giuliani, G. Napolitano, M. Ohmori, G. Laglia, and M. Saji. 1995. The thyrotropin receptor. Vitam. Horm. 50:287-384

3. Levinson, A.I., B. Zweiman, and R.P. Lisak. 1987. Immunopathogenesis and treatment of myasthenia gravis. J. Clin. Immunol. 7:187-197.

4. Engel, W.K., J.L. Trotter, D.E. McFarlin, and C.L. McIntosh. 1977. Thymic epithelial cell contains acetylcholine receptor. Lancet i:1310-1311.

5. Kao, I., and D.B. Drachman. 1977. Thymic muscle cells bear acetylcholine receptors: possible relation to myasthenia gravis. Science (Wash. DC). 195: 74-75.

6. Fuchs, S. I. Schmidt-Hopfeld, G. Tridente, and R. Terrab-Hazdai. 1980. Thymic lymphocytes bear a surface antigen which cross-reacts with acetylcholine receptor. Nature (Lond.). 287:162-164.

7. Hara, Y., S. Ueno, T. Uemichi, N. Takahashi, S. Yorifuji, Y. Fujii, and S. Tarui. 1991. Neoplastic epithelial cells express $\alpha$-subunit of muscle nicotinic acetylcholine receptor in thymomas from patients with myasthenia gravis. FEBS Lett. 279:137-140.

8. Wheatley, L.M., D. Urso, K. Tumas, J. Maltzman, E. Loh, and A.I. Levinson. 1992. Molecular evidence for the expression of nicotinic acetylcholine receptor $\alpha$-chain in mouse thymus. J. Immunol. 148:3105-3109.

9. Mihovilovic, M., and A.D. Roses. 1993. Expression of $\alpha-3, \alpha-5$, and $\beta-4$ neuronal acetylcholine receptor subunit transcripts in normal and myasthenia gravis thymus: identification of thymocytes expressing the $\alpha-3$ transcripts. J. Immunol. 151: 6517-6524.

10. Hara, H., K. Hayashi, K. Ohta, N. Itoh, and M. Ohta. 1993. Nicotinic acetylcholine receptor mRNAs in myasthenic thymuses: association with intrathymic pathogenesis of myasthenia gravis. Biochem. Biophys. Res. Commun. 194:1269-1275.

11. Halsted, W.S. 1914. Significance of the thymus gland in Graves' disease. Bull. Johns Hopkins Hosp. 25:223-234.

12. Michie, W., J.S. Beck, R.G. Mahaffy, E.F. Honein, and G.B. Fowler. 1967. Quantitative radiological and histological studies of the thymus in thyroid disease. Lancet. i:691-695.
13. Franken, E.A. 1968. Radiologic evidence of thymic enlargement in Graves' disease. Radiology. 91:20-22.

14. Van Herle, A.J., and I.J. Chopra. 1971. Thymic hyperplasia in Graves' disease. J. Clin. Endocrinol. 32:140-146.

15. Bergman, T.A., C.N. Mariash, and J.H. Oppenheimer. 1982. Anterior mediastinal mass in a patient with Graves' disease. J. Clin. Endocrinol. Metab. 55:587-588.

16. Gunn, A., W. Michie, and W.J. Irvine. 1964. The thymus in thyroid disease. Lancet. ii:776-778.

17. Baron, R.L., J.K.T. Lee, S.S. Sagel, and R.R. Peterson. 1982. Computed tomography of the normal thymus. Radiology. 142:121-125.

18. Chomczynski, P., and N. Sacchi. 1987. Single-step method of RNA isolation by acid guanidinium thiocyanate-phenol-chloroform extraction. Anal. Biochem. 162:156-159.

19. Libert, F., A. Lefort, C. Gerard, M. Parmentier, J. Perret, M. Ludgate, J.E. Dumont, and G. Vassart. 1989. Cloning, sequencing and expression of the human thyrotropin (TSH) receptor: evidence for binding of autoantibodies. Biochem. Biophys. Res. Commun. 165:1250-1255.

20. Nagayama, Y., K.D. Kaufman, P. Seto, and B. Rapoport. 1989. Molecular cloning, sequence and functional expression of the cDNA for the human thyrotropin receptor. Biochem. Biophys. Res. Commun. 165:1184-1190.

21. Murakami, M., K. Miyashita, M. Yamada, T. Iriuchijima, and M. Mori. 1992. Characterization of human thyrotropin receptor-related peptide-like immunoreactivity in peripheral blood of Graves' disease. Biochem. Biophys. Res. Commun. 186:1074-1080.

22. Murakami, M., K. Miyashita, H. Mizuma, M. Yamada, T. Iriuchijima, T. Takeuchi, and M. Mori. 1996. Discrete characteristics of antibodies raised against thyrotropin receptor-related peptides whose sequences are not conserved in the luteinizing hormone/chorionic gonadotropin receptor. J. Clin. Endocrinol. Metab. 81:1747-1752.

23. Yokoo, H., and Y. Nakazato. 1996. A monoclonal antibody that recognizes a carbohydrate epitope of human protoplasmic astrocytes. Acta Neuropathol. 91:23-30.

24. Mizukami, Y., T. Hashimoto, A. Monomura, T. Michigishi, S. Nakamura, M. Noguchi, and S. Matsukawa. 1994. Immunohistochemical demonstration of thyrotropin (TSH)-receptor in normal and human diseased human thyroid tissues using monoclonal antibody against recombinant human TSHreceptor protein. J. Clin. Endocrinol. Metab. 79: 616-619.

25. Gross, B., M. Misrahi, S. Sar, and E. Milgrom. 1991. Composite structure of the human thyrotropin receptor gene. Biochem. Biophys. Res. Commun. 177:679-687.

26. Graves, P.N., Y. Tomer, and T.F. Davies. 1992. Cloning and sequencing of a $1.3 \mathrm{~kb}$ variant of human thyrotropin receptor mRNA lacking the transmembrane domain. Biochem. Biophys. Res. Commun. 187:1135-1143.

27. Russo, D., G.D. Chazenbalk, Y. Nagayama, H.L. Wadsworth, and B. Rapoport. 1991. A new structural model for the thyrotropin (TSH) receptor, as determined by covalent cross-linking of TSH to the recombinant receptor in intact cells: evidence for a single polypeptide chain. Mol. Endocrinol. 5:16071612 .

28. Ban, T., S. Kosugi, and L.D. Kohn. 1992. Specific antibody to the thyrotropin receptor identifies multiple receptor forms in membranes of cells transfected with wild-type receptor complementary deoxyribonucleic acid characterization of their relevance to receptor synthesis, processing, structure, and function. Endocrinology. 131:815-829.

29. Höhn, E.O. 1959. Action of certain hormones on the thymus of the domestic hen. J. Endocrinol. 19:282-287.

30. Ernstrom, V., and B. Larsson. 1966. Thymic and thoracic duct contribution to blood lymphocytes in normal and thyroxine treated guinea-pig. Acto Physiol. Scand. 66:189-195.

31. Fabris, N. 1973. Immunodepression in thyroid-deprived animals. Clin. Exp. Immunol. 15:601-611.

32. Weetman, A.P., A.M. McGregor, and R. Hall. 1984. Evidence for an effect of antithyroid drugs on the natural history of Graves' disease. Clin. Endocrinol. 21:163-172.

33. Wortsman, J., P. McConnachie, J.R. Baker, and K.D. Burman. 1988 Immunoglobulins that cause a thymocyte proliferation from a patient with Graves' disease and an enlarged thymus. Am. J. Med. 85:117-121. 